\title{
Bruno Bonizzi
}

University of Hertfordshire, UK

\section{Annina Kaltenbrunner}

University of Leeds, UK

At the analytical core of critical macro-finance (CMF) stands a focus on the interlocking balance sheets of financial actors and the differential 'moneyness' of these agents' liabilities. Inherent to this is the view that in contemporary capitalism, money is essentially credit money created by financial institutions. In such a finance-driven and interconnected world, liquidity becomes a crucial factor in determining the rise and fall of economic agents.

By foregrounding the money-creating power of financial institutions and the importance of liquidity, CMF has strong theoretical affinities with Post Keynesian monetary and financial theory. Indeed, as we will argue below, it makes important contributions to the further development of Post Keynesian theory. However, despite regular references to the work of Hyman Minsky, these affinities and contributions are not always spelled out with sufficient clarity. In our contribution to this forum, we suggest that both CMF scholars and Post Keynesian monetary theorists would profit from a more explicit engagement with each other, and together could form powerful foundations for an important and evolving research agenda.

With regards to further developing Post Keynesian theory, CMF has revived and built on the work of various authors who have highlighted the role of institutions and institutional conditions in shaping monetary dynamics. These include, among others, Victoria Chick, Sheila Dow, Jan Kregel, and indeed Hyman Minsky. ${ }^{1}$ Theoretically, it has productively linked the nature of money to the balance sheet characteristics of hierarchical (financial) institutions and the interlocking system of their assets and liabilities. This balance sheet interpretation of money has updated Post Keynesian monetary theory to the new reality of financialised, market-based financial systems.

At the same time, we hold that a more explicit engagement with Post Keynesian monetary theory could provide CMF with a broader theoretical underpinning and link its analysis more effectively to developments in the macro-economy. The work of Minsky and its emphasis on

\section{Corresponding author:}

Bruno Bonizzi, Hertfordshire Business School, University of Hertfordshire, Hatfield AL10 9AB, UK.

Email: b.bonizzi@herts.ac.uk. https://doi.org/10.2218/finsoc.v6i1.4411 
the interrelated assets and liabilities of balance sheets and the fragility which can emerge as a result of a mismatch between the two is, of course, essential to this endeavour. However, Minsky's work was developed from within Post Keynesian monetary theory, in particular via Keynes' liquidity preference theory, and more generally via the assumption that money is credit money endogenously created by the banking system.

In our view, Keynes' liquidity preference theory can provide a useful, existing framework to ground CMF research beyond the work of Minsky, in particular with regards to the nature of money and the 'moneyness' of other assets. The Post Keynesian theory of endogenous money can substantiate the crucial and active role banks play in determining monetary and financial conditions in an economy and the intimate link between these conditions and the macro or 'real' economy. It is this link, which so far remains rather implicit in CMF work, that must be fleshed out in order to demonstrate the wider importance of the CMF project.

\section{Critical macro-finance's contribution to Post Keynesian monetary theory}

CMF effectively links the liquidity of financial institutions with their interlocking assets and liabilities. In the work of Mehrling (2010), Gabor (2016; 2020) and Sissoko (2019) in particular, money markets are central to the dynamics of the financial system: it is in these markets that financial institutions manage the liquidity of their balance sheet, often in the form of collateralised lending. Problems in money markets therefore quickly become systemic as financial fragility is transmitted through interconnected balance sheets and financial institutions react to changing conditions. Moreover, by foregrounding the active behaviour of financial institutions and their ability to create different forms of money, CMF implicitly (and sometimes explicitly, as in Murau and Pforr, 2020) rejects a commodity view of money and instead adopts a credit theory of money. In this view, the liabilities created by hierarchical financial institutions assume varying degrees of 'moneyness' depending on their convertibility into fiat money, i.e., the liabilities of the nation state (see Pozsar, 2014; Gabor and Vestergaard, 2016).

This institution-specific balance sheet approach to financial behaviour within a credit money world is often rooted in the work of Hyman Minsky. Minsky's work also underpins the institutional view of money adopted in these approaches, which puts the asset-liability structure as well as hierarchical relations between different financial institutions at the forefront of discussions on the nature of money and its origination (Gabor and Vestergaard, 2016; Mehrling, 2012; Neilson, 2019; Poszar, 2014).

This balance sheet interpretation of monetary dynamics, which highlights the interplay between the assets and liabilities of hierarchically structured institutions - rather than the properties of different assets themselves - represents an important development of existing Post Keynesian monetary theory. Traditionally, authors who have further developed Keynes' theory of money (the liquidity preference theory) have tended to focus primarily on the specific properties of an asset, which enable it to satisfy holders' liquidity preference in isolation, rather than in relation to the liability structure of that agent. Focus in this work has therefore been on assets' ability to store wealth and the speculative motive for holding money (Carvalho, 1992; Chick, 1983; Davidson, 1978; Dow, 1987). An increase in liquidity preference is here largely due to a general rise in uncertainty in the economy.

Minsky, on the other hand, explicitly considered both sides of the balance sheet and particularly the liability pressures on agents' asset choices (Minsky, 1975; 1980; 1982; 1986). For Minsky (1975: 70), "in a capitalist economy, one way every economic unit can be 
characterized is by its portfolio" which comprises both assets, generating cash inflows, and liabilities, generating cash outflows. Economic units speculate that their liability cash commitments can be met by cash receipts originating from their assets (Mehrling, 2000). CMF adopts and uses this balance sheet vision of economic behaviour to build its powerful account of dynamics in increasingly sophisticated and complex financial markets. In contrast to Minsky, who focused on non-financial corporations as the main drivers of capitalist dynamics, the CMF balance sheet view is instead applied to financial institutions as the key agents of financialised capitalism.

This balance sheet view of monetary dynamics adds to existing Post Keynesian monetary analysis on two grounds. First, asset demand might not only depend on existing portfolio preferences but also arise from the structural pressures of agents' liabilities. Liquidity preference therefore becomes institutionally specific and depends on the nature of agents' liabilities. This means that getting the asset side of things right (for example, through providing market liquidity, prudent economic governance, and so on) might not be sufficient to reduce financial vulnerabilities arising from the liability structure of financial agents (Kaltenbrunner, 2015; Bonizzi, 2017; Bonizzi and Kaltenbrunner, 2018; see also our forthcoming work).

Second, given these structural pressures, a Minskyan/balance sheet framework of hierarchical institutions points immediately to the power creditors can exert over debtors. This includes direct forms of power, for example those that are exerted to ensure repayment, but also indirect ones, in the sense that the conditions affecting creditors will often spill over to debtors, independent of the debtors' conditions themselves. These power relations, as we will discuss below, are particularly evident in cross-border core-periphery balance sheet relations, where funding conditions in core financial markets have fundamental implications for asset dynamics in the periphery. ${ }^{2}$

In sum, CMF's reference to Minsky and its analytical focus on the interlocking balance sheets of hierarchically placed financial institutions draw on and make important contributions to Post Keynesian monetary theory. However, references to Minsky aside, very often this relation remains implicit. Minsky himself though was part of a longstanding wider tradition of Post Keynesian economics and developed his work within this broader theoretical apparatus. The following sections make this relation more explicit and point toward the potential benefits of a stronger engagement between CMF and Post Keynesian monetary theory.

\section{Liquidity preference theory and moneyness}

Although issues of aggregate demand and employment are most commonly associated with Keynes, money and finance have always been at the core of Keynesian economics (see Cottrell, 1994). In the General Theory, for example, Keynes argues that rather than a real variable (as in loanable funds theory), the interest rate is determined in the money market as a price that has to be paid to depart with the security provided by money in a world characterised by fundamental uncertainty (Keynes, 1936: Chapters 13-17). Money is the most liquid asset because it acts as a secure "abode of purchasing power" (Davidson, 1978: 149) and medium of contractual settlement which protects agents from the fundamental uncertainty created by the passing of real (or historical) time. It is held for three motives: the transactional, the precautionary, and the speculative. ${ }^{3}$ While the transactional motive hardly departs from the neoclassical view of money, the precautionary motive, i.e. the need "to provide for contingencies requiring sudden expenditure and ... to hold an asset of which the value is fixed in terms of money to meet a subsequent liability fixed in terms of 
money" (Keynes, 1936: 196), and the speculative motive, which aims at "securing profit from knowing better than the market what the future will bring forth" (Keynes, 1936: 170), both reflect Keynes' innovative idea of a monetary production economy operating under fundamental uncertainty. For Keynes, money is an asset that is chosen from among other assets because of its non-pecuniary return in dealing with an uncertain world: "the possession of actual money lulls our disquietude" (Keynes, 1937: 216).

Whereas Keynes' original liquidity preference theory was a dichotomous choice between two assets (bonds and money), many Post Keynesian scholars have interpreted it as a general theory of asset choice which defines assets along a return-liquidity premium spectrum (Carvalho, 1992; Kregel, 1988; Minsky, 1975; Wray, 1992). In this view, represented in Keynes' own rate of return equation of Chapter 17 in the General Theory, the net benefit of holding an asset involves four elements: a yield $(q)$, a carrying cost $(c)$, an expected appreciation vis-à-vis the numeraire (money) $(a)$, and a liquidity premium $(l)$, where the rate of of return $(r)$ is defined as follows:

$$
r=q+c+a+l
$$

These attributes define a spectrum of assets among which wealth holders can choose, ranging from fixed capital assets, which offer high yield but little liquidity and high carrying costs, to money, for which the yield, carrying cost, and expected appreciation are nil but which offers the highest liquidity premium. Assets with different liquidity premia have to offer different yields to compensate for their relative illiquidity measured against money. The higher an asset's liquidity premium, the closer it is to being money, and the lower the pecuniary return it needs to offer. Liquidity, in turn, is the ability to convert an asset at any time and with little or no loss into money.

This concept of the spectrum of liquidity premium is, in our view, akin to the term 'moneyness' as used in the CMF literature. Rather than through its functions, in this literature money is defined as an asset that trades 'at par on demand' (e.g. Poszar, 2014; Gabor and Vestergaard, 2016). This par convertibility creates a hierarchy of money depending on the ease with which different institutions' liabilities are accepted by hierarchically lower placed institutions and ultimately can be converted into money proper, i.e., fiat money or money issued by the state. Gold serves as money between central banks, central bank reserves as money between banks, bank deposits as money between firms and households (Mehrling 2012), and repos and other short-term financial instruments as money between shadow banks and banks (Poszar, 2014; Gabor, 2016). The easier and more secure the conversion into the money of the state, the higher the moneyness of an asset.

The fact that there is a hierarchy of (short-term) assets depending on their ability to be converted into money proper has been a key insight of Keynes' liquidity preference theory. However, in contrast to CMF's institutionally defined hierarchy of money, from a Post Keynesian monetary viewpoint there is ultimately a clear distinction between money and other assets: there is only one asset that serves as universal unit of account and hence store of value and means of settlement.

Whereas traditionally Post Keynesians have highlighted money's unique ability to store value in the presence of fundamental uncertainty, from a Minskyan perspective, money is the universal unit of account and medium that can settle society-wide obligations denominated in that unit. In a monetary production economy, all the key economic functions are denominated and settled in money terms: wages, taxes, and in particular, debt obligations (see also Michell, 2017). The object that liquidates contractual commitments denominated in the unit of account 
is money, and for this reason it is 'liquid', i.e., its return is a pure liquidity premium. The liquidity premium of other assets, in this Minskyan world, reflects their varying ability to generate cash inflows relative to an investor's liabilities, as well as an investor's ability to convert those assets at no loss into the unit in which their liabilities are denominated, i.e., money. Therefore, liquidity preference does not only depend on the general level of uncertainty in the economy, but also on the demands of agents' existing liability structure, whose obligations are to be settled with money.

This qualifies the primacy that CMF gives to liquidity over solvency (Neilson, 2019: 72). While this primacy is consistent with a Minskyan interpretation of liquidity preference theory, it is important to stress that liquidity preference has a crucial forward-looking component. For many actors in the economy, whether they can "force a unit of cash-flow in [their] favour" (Neilson, 2019: 72-73) involves a substantial degree of speculation about the future. Future payments from liabilities and future inflows from assets are both uncertain and actors adjust their liquidity preference accordingly in order to plan ahead and match inflows with payments. These might look like solvency concerns, but in fact they are about being able to 'make position' in the future, i.e., maintain access to money over the long term.

The uniqueness of money is particularly evident during moments of heightened uncertainty or crisis. Whereas in normal times, other short-term assets can become liquid stores of value with a liquidity premium, and indeed in Minsky's view this 'layering' is inherent to economic booms, in moments of increased uncertainty only money is the universally accepted means to store value and settle obligations. This is important because, as discussed in more detail below, it connects the uniqueness of money to the dynamics of the broader economy. Keynes did not develop liquidity preference theory for its own sake, but because he wanted to show how the demand for money in the presence of fundamental uncertainty, and the interest rate as a price for departing with money, affect investment and hence broader patterns of capitalist development.

Thus, on the basis of a liquidity preference interpretation of Minsky, rather than being institutionally specific, money remains a macroeconomic concept. It is both the universal unit of account for claims and the one means of settling these claims accepted by society as a whole. In today's world, this means of settlement is legally enshrined and supported by the state. Empirically, it currently includes cash, central bank reserves, and bank deposits. Only these assets derive their value purely from their ability to settle transactions, ${ }^{4}$ and their liquidity, unlike that of other assets, is inherent to the design of the (capitalist) monetary system. As Minsky (1986: 78) puts it, "the creation of cash ... is open only to the government and - in a special way - to banks".

\section{Critical macro-finance and endogenous money}

The theory of liquidity preference as expressed in Keynes' General Theory has one very important limitation: it assumes, more or less explicitly, that the money supply is exogenous and fixed by the central bank. Another key issue in Post Keynesian economics has therefore been the development of a theory of endogenous money, that is, a theory in which - in contrast to neoclassical theory, where prior savings finance investment - it is the credit extension by banks which, by simultaneously generating bank deposits, creates most money. Endogenous money creation therefore presupposes a credit view of money.

The precise nature and mechanisms of money's endogeneity have been subject to intense debate among Post Keynesians. The original version of the theory, sometimes known as the 'horizontalist' or 'accommodationist' account (Kaldor, 1985; Lavoie, 1984; Moore, 
1979), states that banks accommodate all demand for money by creditworthy firms. Similar concepts were also developed by the 'monetary circuit' approach (Graziani, 2003; Realfonzo, 2006; Gnos, 2006), which emphasises the circulation of credit money in setting off capitalist accumulation: bank credit extension initiates the circuit of money, which circulates through the economy, and ends with debt repayments to banks. These views have been criticised by 'structuralists' (Chick and Dow, 2002; Dow, 1996; Dow and Dow, 1989) on the grounds that they overlook the importance of liquidity preference in the process of credit supply. Key here is the liquidity preference of banks, which do not passively accommodate the demand for credit but whose decision to lend instead depends on the risk associated with the borrower and the total credit outstanding (lender's risk).

CMF scholarship shares much with the theory of endogenous money. In Mehrling's (2012) hierarchy of money, what counts as money for most actors in the economy are the liabilities of financial institutions (including the central bank for institutions further up in the hierarchy), which are created by banks as a swap of IOUs. Furthermore, Mehrling (2020) considers Dow and Dow's (1987) theory of liquidity preference compatible with his own, so long as it mainly refers to dealers in the money market. However, in abstracting from the origins of the endogenous money literature, CMF risks missing its wider role in explaining macroeconomic dynamics and the role of bank credit in particular. It is in large part for this reason that the CMF literature on shadow banking has come under criticism from Post Keynesian scholars (Michell, 2017; Botta et al., 2019; Bouguelli, 2019, Lavoie, 2019).

First, endogenous money theory makes a clear distinction between initial and final finance that is rooted in wider capitalist dynamics. This is particularly important in circuit theory, where a distinction is made between

the demand for money to finance production (which Keynes called 'finance motive') and the demand for cash reserves (dependent on the transactional, precautionary and speculative motives). The finance motive explains the creation of money and its injection into the economy ... The demand for cash reserves leads to the formation of money stocks which are present at the closure of the circuit. (Realfonzo, 2006: 110-11)

This view is similar to but goes somewhat beyond Mehrling's (2020) distinction between payment and funding, in that it highlights the appearance of money and credit at two different points within the monetary circuit, and thus its connection to the wider economic process of capitalist reproduction. Endogenous money theory's key concern is to explain the workings of a 'monetary economy of production' (Graziani, 2003). While it is certainly possible to abstract from it to explain the payment system, it is not "an obscurity" that the circuit starts with "financing the production of a new capital asset" (Mehrling, 2020: 9). It is the essence of the capitalist economy: capital accumulation for the pursuit of monetary profit, which starts with financing.

Secondly, and as a consequence of the previous point, endogenous money theory highlights the special and active role of banks in determining credit conditions, and the intimate relationship between these conditions and the dynamics of the economy. This is key to understand Minsky's famous 'Financial Instability Hypothesis'. It is the ability and increasing willingness of banks to finance firms' investment plans that underpins the growing balance sheet fragility of the economy over the business cycle. The creation of money by banks still underpins and amplifies capitalist instability. This does not mean that non-bank financial institutions are not important. ${ }^{5}$ As already mentioned, CMF's analysis of market-based finance has tremendously improved our understanding of today's financial dynamics, and Post Keynesian monetary theory is compatible with and enriched by the observation that non-bank 
financial institutions can create further credit in addition to bank credit (see Lavoie, 2019). But banks still remain special in an endogenous money framework, which is ultimately at odds with the claim that "the normal banking transaction [is] the issuance of commercial paper matched by the issuance of money-market fund shares, rather than the creation of a bank loan matched by an increase in deposits" (Neilson, 2019: 15).

\section{Money, Minsky, and external vulnerability in emerging markets}

The analytical power of approaching CMF via a Post Keynesian interpretation of liquidity preference theory and endogenous money can be shown via two examples, both taken from our work on financial fragility and external vulnerability in emerging market economies (EMEs) (Kaltenbrunner and Painceira, 2015; Bonizzi and Kaltenbrunner, 2018). As discussed above, CMF makes a fundamental contribution to Post Keynesian monetary theory by developing an institutionally sensitive form of analysis that takes seriously the liability side of agents' balance sheets. The interdependent nature of balance sheets is arguably even more important in the context of cross-border capital flows, which span different regulatory and currency spaces with significant implications for financial instability. In particular, our work points to the structural pressures arising from cross-border liability structures and the power that international creditors exert over debtors in the Global South. Our Post Keynesian reading of these balance sheet dynamics points to the monetary nature underlying these structures and power relations, as only one currency (currently the US Dollar) can be the global means of settlement and hence the currency of the system. Moreover, it shows the implications these monetary dynamics have for the macro-economy via their influence on key macroeconomic prices, in particular the interest rate and the exchange rate.

Indeed, despite sound macroeconomic fundamentals, record levels of foreign exchange reserves, and a reduction in their foreign currency denominated debt ('original sin'), EMEs have been subject to large and sudden waves of international capital flows, largely independent of domestic conditions. These new forms of external vulnerability, we argue, are due to the fact that whilst foreign investors in EMEs are increasingly prepared to hold EME domestic currency assets, they do not issue their liabilities in them. In other words, whereas foreign investors have increasingly accepted EME currencies as a store of wealth, ${ }^{6}$ they do not use these as unit of account of their financial obligations or means of contractual settlement. By contrast, the US Dollar remains the main international funding currency, denominating more than three-quarters of international liabilities.

This has three consequences for financial stability and key macroeconomic prices (in particular the exchange rate). First, it creates a currency mismatch in foreign investors' balance sheets that makes them highly sensitive to expected exchange rate changes, creating the risk of self-reinforcing feedback dynamics. The second consequence, linked to the fact that foreign investors' liabilities remain denominated in foreign currency and are frequently located in core financial centres, is that it makes their portfolio decisions very dependent on conditions in those markets and de-links them from the specific economic situation in EMEs. Any change in international funding conditions may require these investors to withdraw their investments to meet these liabilities. This shows the structural pressures emanating from agents' liability structures. Finally, these global balance sheet structures create an inherent demand for the global funding currency (the US Dollar), which has been exemplified by the appreciation of the Dollar during the subprime and more recent corona crises. This final point illustrates the implicit - and indeed sometimes explicit - power structures arising out of 
international debtor-creditor relations and the constraints these create for macroeconomic policy and management (Kaltenbrunner and Painceira, 2017).

Our second example focuses on a specific dimension of these broader trends, applying a Minskyan analysis of the vulnerability of demand for EME assets to the behaviour of pension funds (Bonizzi and Kaltenbrunner, 2018). Since the mid-2000s, these large institutions have come to adopt new investment frameworks in response to various structural changes in the financial markets, such as the secular decline in interest rates, their increasing maturity, as well as accounting and regulatory changes. Concretely, pension funds split their portfolio into two sections, one dedicated to 'protecting' the portfolio from the risks of volatile liabilities, the other to 'growing' the size of the portfolio. Crucially, liquidity preference is institutionally driven: the allocation between growth (risky assets producing high expected returns) and protection (liquid assets producing predictable cash-flows) is driven by the overall gap and maturity profile of the pension funds balance sheet. ${ }^{7}$ For pension funds, EME assets cannot match liabilities, and nor are they sufficiently liquid to produce safe cash-flow to settle obligations. Therefore, pension funds demand EME assets only if there is a need for growth, which in turn depends on the institutionally driven liquidity preference of pension funds.

The above describes how the stability of EME asset demand works through the balance sheets of pension funds. This shows a specific way in which EME currencies remain subordinate to other currencies. As they do not generally fulfil the means of settlement function, EME assets are always demanded as risky/satellite assets. Therefore, the demand for EME assets partly depends on their changing ability (or, more importantly, compensation for their inability) to settle liabilities, i.e., to work as 'money' internationally. Crucially, this depends on the global state of liquidity preference, which does not have much to do with EMEs' domestic conditions. Recent debates about global liquidity as a key determinant of international financial flows arrive at a similar point: there is not much EMEs by themselves can do to weather the cycles of global finance.

These examples demonstrate the explanatory promise of a joint Post Keynesian/CMF approach, which combines a detailed institutional analysis of the balance sheets of particular actors with an attention to those factors that have saliency for real economic dynamics, underpinned throughout by an appreciation of the uniqueness of money as the means of settlement and unit of account at the global level.

\section{Conclusion}

In this forum contribution, we have argued that Post Keynesian and CMF scholarship would benefit from a more explicit engagement with each other. CMF is a promising new area of research, which revives and expands Minskyan ideas about liquidity and balance sheets. Post Keynesian scholars would benefit from the detailed empirical insights that CMF provides, particularly through its analysis of non-bank financial institutions and the conceptual focus on liquidity and liabilities. On the other hand, the CMF literature would benefit from more explicit grounding in earlier Post Keynesian concepts. In particular, the theory of liquidity preference and the concept of the liquidity premium point towards the uniqueness of money as a means of settlement and unit of account. The theory of endogenous money highlights the special nature of banks and the circulation of money in the real economy. In short, Post Keynesians would do well to engage with the 'finance' in CMF scholarship, while CMF scholars would do well to engage with the 'macro' in Post Keynesian economics. After all, Minsky and Keynes' unique ability to combine realistic macroeconomics with finance is what makes their insights timeless. 


\section{Notes}

1. Minsky's theory has also been developed in at least two other directions by Post Keynesian authors. One of these focuses on the modelling of financial instability; the other contributed to the development of Modern Monetary Theory, mainly through Randall Wray, who was Minsky's PhD student.

2. See also Sissoko (2019), who argues that the current market-based system has further strengthened the power of creditors due to repo market lending.

3. Although separating these different motives analytically, Keynes (1997: 195) also stressed that the "money held for each of the three purposes forms, nevertheless, a single pool, which the holder is under no necessity to segregate into three water-tight compartments".

4. These views are shared by proponents of Modern Monetary Theory. Bell (1998: 8), for example, argues that "neither the State nor the banks rely on convertibility for acceptance of their promises; what makes them both acceptable is not convertibility into something else but acceptance in payment to one's creditors" (emphasis added).

5. Indeed, our research on emerging economies focused on the role of non-bank institutions in driving capital flows and determining exchange rates (Bonizzi and Kaltenbrunner, 2019; forthcoming).

6. However, de Souza Lima Orsi (2019) argues that rather than seeking true stores of wealth, these investments are instead speculative and short term.

7. In practice this consists in minimising funding (i.e., asset/liability) gaps by hedging various types of risk (especially interest rate risk) and ensuring liquidity in the short run.

\section{References}

Bell, S. (1998) The hierarchy of money. Levy Economics Institute Working Paper, 231.

Bonizzi, B. (2017) An alternative Post Keynesian framework for understanding capital flows to emerging markets. Journal of Economic Issues, 15(1): 137-62.

Bonizzi, B. and Kaltenbrunner, A. (2018) Liability driven investment and pension fund exposure to emerging markets: A Minskyan analysis. Environment and Planning A: Economy and Space, 51(2): 420-39.

Bonizzi, B. and Kaltenbrunner, A. (Forthcoming) An alternative Minskyan framework of capital flows and exchange rate dynamics in developing and emerging economies. In: Bonizzi, B., Kaltenbrunner, A. and Ramos, R. (eds.) Financial Integration and Exchange Rates in Emerging Economies: The Contribution of Post Keynesian Economics. London: Routledge, in press.

Botta, A., Caverzasi, E. and Capelli, C. (2019) Shadow banking and the financial side of financialisation. Cambridge Journal of Economics, 43: 1029-51.

Bouguelli, R. (2019) Is shadow banking really akin to banking? A critical analysis in light of monetary theory. Journal of Post Keynesian Economics, 43(1): 1-27.

Carvalho, F.J.C. (1992) Mr. Keynes and the Post Keynesians. Aldershot: Edward Elgar.

Chick, V. (1983) Macroeconomics After Keynes. Oxford: Philip Alan.

Chick, V. and Dow, S. (2002) Monetary policy with endogenous money and liquidity preference: A nondualistic treatment. Journal of Post Keynesian Economics, 24(4): 587-607.

Cottrell, A. (1994) Post Keynesian monetary economics. Cambridge Journal of Economics, 18(6): $587-$ 605.

Davidson, P. (1978) Money and the Real World. London: Macmillan.

de Souza Lima Orsi, B. (2019) Currency Internationalisation and Currency Hierarchy in Emerging

Economies: The Role of the Brazilian Real. Doctoral thesis (PhD), University of Leeds.

Dow, S.C. (1996) Horizontalism: A critique. Cambridge Journal of Economics, 20(4): 497-508. 
Dow, A. and Dow, S.C. (1989) Endogenous money creation and idle balances. In: Pheby, J. (ed.) New Directions in Post Keynesian Economics. Aldershot: Edward Elgar, 147-64.

Gabor, D. (2016) The (impossible) repo trinity: The political economy of repo markets. Review of International Political Economy, 23(6): 967-1000.

Gabor, D. (2020) Critical macro-finance: A theoretical lens. Finance and Society, 6(1): 45-55.

Gabor, D. and Vestergaard, J (2016) Towards a theory of shadow money. INET Working Paper Series.

Gnos, C. (2006) French circuit theory. In: Arestis, P. and Sawyer, M. (eds.) A Handbook of Alternative Monetary Economics. Aldershot: Edward Elgar, 87-104.

Kaldor, N. (1985) The Scourge of Monetarism. Oxford: Oxford University Press.

Kaltenbrunner, A. (2015) A Post Keynesian framework of exchange rate determination: A Minskyan approach. Journal of Post Keynesian Economics, 38(3): 426-48.

Kaltenbrunner, A. and Painceira, J.P. (2015) Developing countries' changing nature of financial integration and new forms of external vulnerability: The Brazilian experience. Cambridge Journal of Economics, 39(5): 1281-306.

Kaltenbrunner, A. and Painceira, J.P. (2017) The impossible trinity: Inflation targeting, exchange rate management and open capital accounts in emerging economies. Development and Change, 48(3): 452-80.

Keynes, J.M. (1936). The General Theory of Employment, Interest and Money. London: Macmillan. Keynes, J.M. (1937) The general theory of employment. The Quarterly Journal of Economics, 51(2): 209-23.

Kregel, J.A. (1988) The multiplier and liquidity preference: Two sides of the theory of effective demand. In: Barrère A. (ed.) The Foundations of Keynesian Analysis. London: Palgrave, 231-50.

Lavoie, M. (1984) The endogenous flow of credit and the Post Keynesian theory of money. Journal of Economic Issues, 18(3): 771-97.

Lavoie, M. (2019) Advances in the Post Keynesian theory of money and finance. In: Arestis, P. and Sawyer, M. (eds.) Frontiers of Heterodox Economics. London: Palgrave Macmillan, 89-129.

Mehrling, P. (2000) Minsky and modern finance: The case of Long Term Capital Management. The Journal of Portfolio Management, 26(2): 81-88.

Mehrling, P. (2010) The New Lombard Street: How the Fed Became the Dealer of Last Resort. Princeton, NJ: Princeton University Press.

Mehrling, P. (2012). The inherent hierarchy of money. In: Taylor, L., Rezai, A. and Thomas, M. (eds.) Social Fairness and Economics: Economic Essays in the Spirit of Duncan Foley. London: Routledge, 394-405.

Michell, J. (2017) Do shadow banks create money? 'Financialisation' and the monetary circuit. Metroeconomica, 68(2): 354-77

Minsky, H.P. (1975) John Maynard Keynes. New York, NY: Columbia University Press.

Minsky, H.P. (1980) Capitalist financial processes and the instability of capitalism. Journal of Economic Issues, 12(2): 505-23.

Minsky, H.P. (1982) Can "It" Happen Again? Essays in Instability and Finance. New York, NY: M.E. Sharpe.

Minsky, H.P. (1986) Stabilizing and Unstable Economy. New Haven, CT: Yale University Press.

Moore, B.J. (1979) The endogenous money stock. Journal of Post Keynesian Economics, 2(1): 49-70.

Murau, S. and Pforr, T. (2020) What is money in a critical macro-finance framework? Finance and Society, 6(1): 56-66.

Neilson, D. (2019) Minsky. Cambridge: Polity

Pozsar, Z. (2014) Shadow banking: The money view. Office of Financial Research Working Paper, 04.

Realfonzo, R. (2006) The Italian circuitist approach. In: Arestis, P. and Sawyer, M. (eds.) A Handbook of Alternative Monetary Economics. Aldershot: Edward Elgar, 105-20. 
Sissoko, C. (2019) Repurchase agreements and the (de) construction of financial markets. Economy and Society, 48(3): 315-41.

Wray, R. (1992) Alternative theories of the rate of interest. Cambridge Journal of Economics, 16(1): 6989. 